\title{
Lexico-Semantic 'Intraference' in Educated Nigerian English (ENE)
}

\author{
Steve Bode Ekundayo ${ }^{1}$ \\ ${ }^{1}$ Department of English and Literature, University of Benin, Benin City, Edo State, Nigeria \\ Correspondence: Steve Bode Ekundayo, Department of English and Literature, University of Benin, Benin City, \\ Edo State, Nigeria. E-mail: ekuns20@yahoo.com
}

\author{
Received: September 23, 2013 Accepted: October 24, 2013 Online Published: November 24, 2013 \\ doi:10.5539/ijel.v3n6p17 \\ URL: http://dx.doi.org/10.5539/ijel.v3n6p17
}

\begin{abstract}
This paper examines the concept and features of lexico-semantic 'intraference' in Educated Nigerian English (ENE). The tendency of nonnative speakers in a(n) ESL setting, like Nigeria, to redeploy the lexico-semantic rules of English to 'kill,' weaken, strengthen and reverse the SBE and native English meanings of words is termed lexico-semantic intraference in this paper. Questionnaires, interviews, library research, empirical studies, the Internet and recording of live linguistic events were used to gather data from 2004 to 2013. It was discovered that educated Nigerians regularly impose meanings on some words, extend the meanings of words, weaken or reverse word meanings and also redeploy the lexico-semantic dynamics of the language to fabricate lexical items with new meanings or meanings already in some well established SBE words. These habits generate words and meanings that distinguish ENE lexico-semantics from the lexico-semantics of SBE and some other international varieties of English.
\end{abstract}

Keywords: intraference, lexico-semantics, Nigerian English, ESL, SBE, sociolinguistics

\section{Introduction}

Lexico-semantics is a sub-branch of Semantics that deals with the study of words and meanings and the relatedness of lexical items in syntagmatic structures. Words either denote physical and abstract things or connote images in the real and imagined worlds (Yule, 2003). Neologism, semantic and metaphoric extension, conversion, broadening and layering, narrowing or semantic attrition, semantic shift and drift and semantic reversal are the major lexico-semantic processes in English (Akmajian, Farmer, Dermer \& Harnish, 2006; Aitchison, 2001; Crystal, 2009).

In lexico-semantic intraference, the semantic rules and dynamics of a second language (L2) are moved from one section of L2 where they operate acceptably to another section where they used not to apply, hence the habit is tagged 'intraference' in this paper since the deployment of semantic rules happens within the language. This is unlike lexico-semantic interference where the first language and/or mother tongue (L1 and/or MT) semantic system is imposed on the second language lexical items. Lexico-semantic intraference occurs in different ways.

The first way is by the imposition or transfer of an extra, (un)related meaning to a word. In this case, a meaning that is already established in some words in SBE is imposed on another word that does not have the meaning in SBE; for example, blocking in ENE has the added meaning of bribery, payment in cash or kind to influence a lecturer or someone to pass a student or upgrade their marks in higher institutions. Second, lexico-semantic intraference can manifest in the weakening or reduction of meaning from a word; for example, impeach in ENE is hardly used to denote accuse, indict, doubt, as in SBE. In ENE impeach is widely used to mean remove a political officer from office by parliamentary votes, as in American English. Third, a lexical meaning may be strengthened to have more layers of related meanings, e.g., the use of several in ENE means many, not just three or few. Furthermore, lexico-semantic intraference can show in the yoking of two similar meanings in the same context to generate lexico-semantic repetition, e.g., night vigil, some certain things. Also, two opposite or contrasting meanings could be forced on a word; for example, bad for both what is not good and sometimes for something wonderful, or mischievously pleasant. Lastly, conversion may be used to change the meaning and class of a word, as in converting a noun or adjective to a verb. Educated Nigerians generally redeploy these semantic processes with word-formation processes to create an array of words and meanings.

The purpose of this paper is to document such words and meanings and show how they distinguish Nigerian English lexico-semantics from SBE lexico-semantics. Several research questions guided the researcher in 
gathering the intended lexico-semantic features in ENE: Do educated Nigerians redeploy lexico-semantic processes to invest English words with new or additional meanings? Do educated Nigerians use lexico-semantic processes to divest English words of extant meanings? Do educated Nigerians reverse the meanings of words in their everyday use of the words? To what extent do the words distinguish ENE lexico-semantic features from those of SBE and any other international varieties?

\subsection{Method of Research}

Questionnaires, interviews, library research, empirical studies, the Internet and recording of live linguistic events were used to gather data for this research. Subjects were between 19 and 70 years mainly (but not wholly) professors, lecturers and final year and post-graduate students of English and Literature, Linguistics, and Communication Departments in ten (10) universities and five (5) colleges of education owned by state government, and ten (10) universities and five (5) colleges of education owned by the Federal Government of Nigeria in ten cities across five geo-political/geo-linguistic zones of Nigeria were tested from April 2004 to March 2013. The cities are Lagos, Ibadan, Kano, Kaduna, Benin, Port Harcourt, Abuja, Owerri, Calabar and Ilorin. Besides, the spontaneous speeches of many educated Nigerians were covertly and overtly observed and recorded across Nigeria.

The interviews were mainly unstructured and the questionnaires were cast in multiple choices with options A and $\mathrm{B}$, or A to D, as the case may be. Option A has the popular native or SBE form while option B has the ENE sense of the word. Respondents were asked to tick, ring or fill in a blank space the option that they frequently used. Cases got from observation and recording of live language events and written texts were further tested in interviews and questionnaires to establish their popularity among educated Nigerians. The questionnaires and interview were validated by two professors of Test and Measurement and two professors of English and Literature of the University of Benin before they were administered to subjects. Thereafter, their performances were collated and analyzed. Where forty to fifty percent ( 40 to $49 \%$ ) of the population tested picked or ticked an option, that particular option is treated as an emerging feature or variant in ENE. Cases with 50 to $59 \%$ are treated as common; $60-79 \%$ are widespread and 80 to $100 \%$ are tagged entrenched. On the whole, no fewer than 60, 000 Nigerians were studied. The distributions of responses are presented in simple percentile count in tables and serial annotations. There are other examples from live linguistic events and published works annotated alongside SBE and/or SAE forms.

The method of research is, therefore, eclectic. It is both qualitative and quantitative. The qualitative method is used to describe the lexico-semantic variations gathered and to explain their psycho-sociolinguistic underpinnings. Qualitative research is concerned with individual's own accounts of attitudes, motivations and behaviour. The qualitative approach is best suitable for exploratory, attitudinal, historical and linguistic studies that examine causal processes at the level of the intentional, self-directing and knowledgeable actor (Omorogiuwa, 2006). However, the quantitative approach is used to present the statistics of responses in tables accounting for the specific frequency, ubiquity and percentage of the cases documented. These two methods are best for the intuitive nature and psycho-sociolinguistic features of this study. They also enable readers to quickly and simply appreciate the data that substantiate, or can be used to justify, the claims and intuitive propositions made in this study.

\subsection{Theoretical Framework and Review of Related Scholarship}

This survey is anchored on four related works and theories/concepts; namely, Labov's propositions in his seminal works on variationist sociolinguistics $(1963,1969,1972,1994,2001$ and 2010). Selinker's $(1971,1984)$ concept of "Interlanguage", Richards' and Sampson's (1984) concept of "intralingual interference" and Ekundayo's $(2006,2012)$ concept of "Intraference".

Labov (1994) demonstrated that the forces of language change and variations are embedded in the linguistic system/properties and social dynamics. The linguistic properties "are in the grammar and they constrain the grammar, and they cannot be described" without reference to the grammar. Further, he asserts that morphological and syntactic variables are informed by "semantic distinctions and/or structural configurations whose development can be traced in the history of the language" (p. 84). Both linguistic and extralinguistic factors work together to engender variations and varieties of a language (Milroy, 2008). The ENE and its features of this study are clear examples of the result of the interplay of linguistic and extralinguistic forces of variations. Naturally placed in a heterogeneous second language situation that is far away from a native English setting, educated Nigerians are constrained to manipulate the grammatical system of English and redeploy lexico-semantic features and rules to create words whose meanings are already well-expressed in some other established words in SBE. Bayley (2007) captures the nature and focus of variationist sociolinguistic research as follows: 
Research in variationist approach, in contrast to research that seeks a single overarching explanation, assumes that interlanguage variation, like variation in any language, is likely to be subject to the influence of not one but multiple contextual influences. That is, variationist research, whether on native or non-native languages, adopts what Young and Bayley (1996) have referred to as the principle of multiple causes (p. 135) (Bold emphasis mine).

Selinker (1984) says that "interlangauge" is what results from a second language learner's attempted production of a target language norm (TL norm), which is different from the corresponding set of expressions a native speaker of the target language (TL) in the same context may produce. Selinker subsequently suggests that "the investigator in the psychology of second language learning can begin to study "the processes that lead to the knowledge behind interlanguage" and "the factors that lead to the knowledge underlying interlanguage" (p. 37). (Bold emphasis mine). Selinker expands "the processes" and "the factors" into five interrelated features: (1) language transfer, (2) transfer of training, (3) strategies of learning, (4) strategies of communication, (5) over generalization of linguistic materials and semantic features (1971, pp. 35, 43; 1984, p. 37).

Different linguists have variously described this fifth phase of interlanguage in long constructs and terminologies. Selinker (1984) calls it "overgeneralisation of linguistic materials and semantic features" (p. 37), but Richards and Sampson (1984) variously reduced this long construct to a two or three-word phrase: "systemic intralingual errors," "intralingual interference" and "internal language transfer" (pp. 6-10). Labov (1994) describes them as the internal principle of linguistic change. What they denote in various long terms has been lexicalized and conceptualized as intraference (Ekundayo, 2006, pp. 6-20; Ekundayo, 2012, pp. 1-20). What then is intraference?

\subsubsection{The Concept of Intraference}

Intraference is the habit of redeploying the rules, dynamics and semantic properties of a language from a section where they have been established and acceptably operate to another section within the language where they hitherto used not to operate. Since such a transfer is within the language, it has been lexicalized as intraference, as the reverse of interference. Intraference is coined from the senses of inter, intra, and interference. Intra means in, within, or inside. When used to form a word, intra denotes or connotes something happening within an entity, not outside it, and not connecting a different or analogous entity; for example, intracity means 'in or within a city', not 'outside it'. Both intra and inter inherently suggest the contact of two things. Intra suggests a contact of two sub-items in the same family or entity while inter suggests the meeting or clash of two entities of equal (or unequal) rank, but surely from different families or classes.

Etymologically, interference, the well established term, is an amalgam of two morphemes, which are inter and ferire. They come from Old French as inter (between) plus (+) ferire (to strike). Thus interference means a strike or contact between two things (Funk \& Wagnalls, p. 339). Intra is combined with ferire to have intra-ferire. Analogically, intra (within) plus (+) ferire (to strike or contact) means to disturb, strike or make two things contact each other within an entity. In the context of this work, it is a contact within an entity, which is language. The -ference is the noun formation, meaning an internal contact or disturbance within, that is linguistic intraference. Essentially, our coinage is motivated by the desire to offer a more precise, lexicalized and economical term for the linguistic features that have been variously described in long terminologies; for economy and precision of terms are preferred in linguistics.

Intraference relates to the underlying "competence," which informs the redeployment of language items and rules to fabricate and use words and meanings. It is concerned primarily with nonnative speakers who do not understand their second language perfectly and are affected by such psycho-sociolinguistically relevant conditions as setting, context, memory limitations, distractions and shifts of attention and interest. They are further affected by the phonological, orthographical, syntactic and semantic rules, exceptions and items that are characteristic of the second language, as they apply his knowledge in actual performance (a adaptation of Chomsky's $(1965$, p. 3) fine phraseology. In this conceptualization, two major factors that affect the competence and performance of a second language user are the psycho-sociolinguistic/and the linguistic.

Now, the psycho-sociolinguistic relates to the user's setting, social knowledge and brain or mind, the way the user views and rearranges the language creatively or otherwise in his mind. It relates to what Chomsky terms "competence" and "performance." While competence refers to the underlying innate linguistic knowledge of the native speaker, performance denotes the practical, actual use of language in a given situation. As the native speaker possesses competence so the educated nonnative speaker possesses some competence, which is not on a par with that of a native speaker. However, both the native and the nonnative speakers must necessarily apply their knowledge to perform a linguistic event. Different sociolinguistic settings generate different competences 
and different competences lead to different performances.

The second of the two major factors is linguistic, which is sub-divided into the five main levels of linguistic organization. In effect, intraference manifests at the phonological, graphological, morphemic, syntactic and lexico-semantic levels. In this paper, features of the lexico-semantic level are examined in Nigerian English.

\subsubsection{The Concept of Nigerian English}

The terms "Nigerian English," "Educated Nigeria English," "Standard Nigerian English," etc have been in currency since pre-Independence Nigeria. Nigeria gained her Independence from the British colonialists on October 1st 1960. However, the terms were ambiguous and controversial when they initially became popular. According to Jowitt (1991), "it was natural for many Nigerians and many of the expatriates numerous in the schools and universities in 1960s to use the expression 'Nigeria English' without feeling any need to apologize" (p. 30). Nigerian English is classified according to region, sociolinguistic features, educational status and linguistic features. The most popular classification is Banjo's Varieties I, II, III and IV. Variety I is associated with primary school pupils and leavers, II is common with secondary school students and leavers and a majority of Nigerians. It is characterized with interference and grammatical deviations. III is associated with educated Nigerians as depicted in the next paragraph. Banjo proposes Variety III as Nigerian model because it has 'intranational' prestige and international intelligibility. Variety IV is identical to SBE or RP, or SAE used by very few Nigerians who acquired English in native English speaking settings or have a native-English speaking parent. This variety is generally considered too foreign or laced with non-Nigerian accent (Banjo, 1996, pp. 96-100).

Specifically, "Educated Nigerian English," also called "Standard Nigerian English," is used here to mean the type of English used by Nigerians who have (i) a post-secondary school qualification like National Diploma (ND), National Certificate of Education (NCE), Higher National Diploma(HND), (ii) a first degree in any field: B.A. (Ed) B.Sc. (Ed) and B. Ed, (iii) university and tertiary institution students, (iv) more than a first degree like M.A, M.Sc. and Ph.D., (v) senior government and private-sector workers and other literate Nigerians who may not have the qualifications listed above, but have had trainings, interacted widely with educated people over a time, or have travelled widely, or have a sound family and/or educational background and so use ENE. Some educated people's performances fall below ENE, just as we have people who are not of this class who speak ENE. This is why we have included number five.

There are two major types of ENE: formal ENE and informal ENE. Formal ENE is the variety used for teaching and learning in schools, for broadcast, for interaction with English-speaking foreigners, for writing and for official interaction in offices and parliaments. Formal ENE is further divided into the written and the spoken types. The written type is like SBE in syntactic patterning and orthography, but there may be lexical variations arising from borrowings and intraference. The spoken type is typically Nigerian with phonological interference as well as an admixture of correct SBE and/or SAE articulation. Unlike the formal type of ENE, the informal type is largely spoken and used in casual, unofficial/non-official, friendly, sociable contexts and situations. It is more fluid and less pedantic. Sometimes, it may be written for stylistic purposes.

\subsubsection{The Lexico-Semantics of Nigerian English}

It has been observed that Nigerians display the linguistic tendency of stretching the meanings of words beyond their assigned dictionary and native meanings for sociolinguistic, cultural and pragmatic reasons (Adegbija, 1989; Odumuh, 1980; Bamiro, 1994). Neologisms and meaning extension have also been found to be "the defining characteristic" of Nigerian English (Teilanyo, 2008, p. 29). According to Effiong (2011), Nigerians coin words and expressions which may not have the same meanings in native-English usage. Such linguistic innovations or "semantic contrasts" distinguish Nigerian English (pp. 286-7). Similarly, Osakwe (2011) says that young Nigerians take advantage of Nigeria's complex sociolinguistic background to produce "slangs (sic) and nonstandard usages" showing "semantic drift" (p. 33). In this connection, this paper demonstrates that Nigerians impose, extend or add, convert, weaken and reverse the meanings of words by redeploying the lexico-semantic rules and processes of English, which is here tagged 'lexico-semantic intraference.'

\section{Data Analysis}

\subsection{Lexico-Semantic Intraference for Ten Words on Questionnaire}

Ten words (impeach, diabolic, decamp, come down, take in, celebrant, flirt, offering, toast and dash) were administered to five thousand subjects each in ten higher institutions in ten Nigerian cities (See appendix). Below is a table showing the simple percentile count of responses: 
Table 1. Percentages of responses for lexico-semantic intraference for ten words

\begin{tabular}{|c|c|c|c|c|c|c|}
\hline $\mathbf{S} / \mathbf{N}$ & Words & SBE Meaning & $\begin{array}{l}\text { Percentage } \\
\text { of SBE over } \\
50000\end{array}$ & ENE Meaning & $\begin{array}{l}\text { Percentage of } \\
\text { ENE over } \\
50000\end{array}$ & Comment \\
\hline 1 & Celebrant & $\begin{array}{l}\text { A priest conducting Mass } \\
\text { or someone conducting a } \\
\text { ritual. }\end{array}$ & $3000 / 10 \%$ & $\begin{array}{l}\text { Someone celebrating } \\
\text { a birthday or some } \\
\text { form of achievement. }\end{array}$ & $47000 / 90 \%$ & Entrenched \\
\hline 2 & Come down & $\begin{array}{l}\text { Step down/alight from a } \\
\text { vehicle }\end{array}$ & $10000 / 20 \%$ & $\begin{array}{l}\text { To come out of a } \\
\text { vehicle }\end{array}$ & $40000 / 80 \%$ & Entrenched \\
\hline 3 & Dash & $\begin{array}{l}\text { (V.) to do something } \\
\text { quickly, something added } \\
\text { to something; part of a car } \\
\text { (dashboard). }\end{array}$ & $3000 / 6 \%$ & $\begin{array}{l}\text { (V.) Give, offer } \\
\text { money or something } \\
\text { as a gift; go } \\
\text { somewhere fast. (N.) } \\
\text { A gift. }\end{array}$ & $47000 / 94 \%$ & Entrenched \\
\hline 4 & Decamp & Defect & $5000 / 10 \%$ & $\begin{array}{l}\text { To change political } \\
\text { party }\end{array}$ & $45000 / 90 \%$ & Entrenched \\
\hline 5 & Diabolic & $\begin{array}{l}\text { Wicked, malicious, } \\
\text { disgusting }\end{array}$ & $10000 / 20 \%$ & $\begin{array}{l}\text { Describes a } \\
\text { witch/wizard or one } \\
\text { who uses charms and } \\
\text { magic to achieve } \\
\text { things: good or evil }\end{array}$ & $40000 / 80 \%$ & Entrenched \\
\hline 6 & Flirt & $\begin{array}{l}\text { To keep several opposite } \\
\text { friends, but not necessarily } \\
\text { having sex with them. To } \\
\text { be fond } \\
\text { something/somebody. }\end{array}$ & $5000 / 15 \%$ & $\begin{array}{l}\text { To keep and have sex } \\
\text { with several sex } \\
\text { partners; one who } \\
\text { does this. }\end{array}$ & $45,000 / 90 \%$ & Entrenched \\
\hline 7 & Impeach & To indict, accuse, impugn & $5000 / 10 \%$ & $\begin{array}{l}\text { To remove one from } \\
\text { office by vote. }\end{array}$ & $45000 / 90 \%$ & Entrenched \\
\hline 8 & Offering & Offertory & $3000 / 5 \%$ & $\begin{array}{l}\text { Money giving } \\
\text { willingly in church, } \\
\text { usually in a } \\
\text { container.during } \\
\text { church service. }\end{array}$ & $47000 / 95 \%$ & Entrenched \\
\hline 9 & Take in & Deceive & $3000 / 5 \%$ & To get pregnant & $47000 / 95 \%$ & Entrenched \\
\hline 10 & Toast & $\begin{array}{l}\text { Related to baking, or } \\
\text { proposing a toast in a social } \\
\text { function }\end{array}$ & $10000 / 20 \%$ & $\begin{array}{l}\text { Talk to a girl } \\
\text { pleasantly to win her } \\
\text { love. }\end{array}$ & $40000 / 80 \%$ & Entrenched \\
\hline
\end{tabular}

Other examples extracted from spoken and written ENE were also tested among ten thousand students and academics of the same universities from 2010 to 2013. The percentage of response for ENE sense B is put in the front of each word. Those without percentages were not tested but observed and known to be widespread or entrenched in ENE.

\subsection{Imposition and Tranference of Meaning}

\section{Belgium}

It is entrenched in informal ENE, often used to describe second-hand or used vehicle and machine parts, sometimes regarded as superior to counterfeit new parts. It is also used to describe hand-me-downs or anything second hand: "Buy Belgium engine; don't buy new engine." "How is your Belgium girl friend?"

Blast (77\% popular in informal ENE).

It is informally used for to pass very well in flying colours, with top grades in an exam: "Jude blasted 
five A's and two B's in the last exam."

$\operatorname{Boy}(\mathbf{s})$

(i) (A) young energetic loyalist(s) who do/es the biddings of their master(s): "I will call up my boys to deal with him." (ii) Someone who received/receives training, initiation and mentorship from a more experienced and older person: "I have sent him to one of my boys." (iii) (An) army and paramilitary officer(s) who is/are under the command of (a) senior officer(s).

Crash (75\% widespread in informal ENE).

An informal, colloquial word for to sleep, fail or fall: "I want to crash for some minutes" (sleep). "The deal has crashed" (failed).

Public dog (69\% widespread)

A derogatory term used to demean a girl/woman who is an easy lay, who keeps multiple sex partners.

Settle

In addition to its SBE sense, to settle in ENE means to bribe or placate: "We will settle the policemen to gain entrance".

\section{Settle down}

To get married, start raising children and behaving responsibly in society: "She says that she will settle down soon."

Spin (90\% widespread informal ENE, also toast ).

Spin/toast means to woo or talk to a woman pleasantly to win her love or friendship.

Sweet Sixteen (100\% entrenched)

Sexy teenagers and girls in their sexual prime, particularly in the company of older men.

To form/forming ( $62 \%$ wide spread in informal ENE).

Besides SBE sense, to form form/ forming in Informal ENE is to pretend, to assume air, make believe, behave as if something is wrong when indeed nothing is wrong and vice versa: "They branded me as one who forms a lot" (University Exam Script, 0900332: 3)

\section{This thing}

A euphemism, vulgar or funny word for the privates or sexual organ.

Woman wrapper (100\% entrenched more in informal ENE and also in formal ENE)

A womanizer, particularly one who can do anything to please a woman; a man easily controlled by his wife/girlfriend.

\subsection{Extension, Addition of Extra Layers and Strengthening of Meaning}

\section{Bang/banging}

Informal ENE for sex or to have sex. "That babe likes banging."

Branch (65\% widespread)

It is used in ENE with the additional meaning of stop over in a journey, or walk, to see someone or do something, a meaning not found in SBE branch: "My uncle and I branched to the Southern Fried Chicken Fast Foods..." (University Exam Booklet Art, 0905565:3). "As we arrived at Sapele, we branched into a fast foods joint for refreshment" (University Exam Booklet Art, 090355:2)

\section{Busy body}

Informal ENE for one who is hyperactive, excited or meddlesome.

\section{Carry-over}

An entrenched form in ENE, particularly in higher education and institutions, for a course failed to be retaken in the following session.

Cash and carry (96\% entrenched)

In SBE, cash and carry refers to a wholesale store where large goods are sold at moderate or low prices to buyers to take away themselves. In ENE, however, cash and carry means 'spend money to get 
something' or 'influence decisions and results, bribe/bribery, rightly or wrongly' or 'if you spend cash, you get it.' When a process, situation, thing or someone is described as 'cash and carry,' it means they are achievable, manipulable, winable with money. A cash and carry madam or lady is either a whore or one who gives in once you spend on her: "Nigerian politics is cash and carry."

Chance (100\% entrenched)

Through meaning expansion, chance is used to convey more meanings of room for someone to seat or something to occupy, say in a vehicle or place. "There is no chance for you to sit." SBE would be There is no room/space for you to sit. No chance in SBE means not likely, may not be possible. In .ENE it additionally means no room, no space, no time.

Chase (90\% in informal ENE).

Also used in the sense of toast and spin above, chase goes beyond mere talks to include concerted efforts made to win a lady's love. "My boss has been chasing me seriously. I don't know what to do."

Chill (80\% entrenched in informal ENE)

It has the added meaning of to relax, to be patient, calm. Speaker A: "Where is my money?" Speaker

B: Chill! You'll get your money back shortly."

Colleague ( $81 \%$ entrenched)

In SBE and SAE, this means one that you work with in the same office or firm, a professional mate, but in ENE, it is generally used to denote a fellow worker, course/classmates, roommates or someone with whom you are doing anything. "I will come with my roommates and colleagues to the party."

\section{Concoction (rice)}

Food hurriedly or imperfectly cooked or put together because one does not have the complete ingredients or time to prepare them.

Cram (100\% entrenched)

A word entrenched or widespread in students usage at all levels of the Nigeria educational system, it is used to mean to memorise, internalise a note, passage, figures, data, etc with a view to regurgitating them off hand during exam or when required. Cramming is often juxtaposed with reading and understanding: "I just crammed my note and poured everything for him. I didn't really understand those things."

Far-fetched (61\% widespread)

In SBE, far-fetched means unlikely, fake, exaggerated, unreasonable; for example, "The theory is too far-fetched to be considered". But in ENE, (not) far-fetched is often used to mean (not) far away, (not) distant, (not) hard to find or give, it is obvious, etc: "Actually, we are starting on a sad note and the reason is not far-fetched" (Maduagbunam, 2011).

\section{Freedom}

In addition to its SBE meanings, freedom in ENE means a ceremony/celebration organized to symbolize or mark the end of one's apprenticeship, trade, skill acquisition and tutelage. A certificate of competence is usually given to the apprentice during this ceremony. Thereafter, the apprentice is now 'free' or independent with his master's blessings to run the trade and also have apprentices. It is a kind of 'convocation' for a semi-formal trade and skill-acquisition school: "I have gained my freedom from my oga." "I am doing my freedom next month."

Gist/to gist (100\% entrenched in informal ENE)

(i) To chat or gossip, to share light, humorous or interesting stories; (ii) conversation about social and personal experiences.

Grammar (78\% widespread, particular in informal ENE).

Apart from its regular meanings, grammar in informal ENE means high-sounding expressions/utterances that one does not understand or regards as senseless. "You are just speaking grammar" means you are speaking high-sounding English, or you are not making sense.

Kill and divide (Popular particularly in the Civil Service and government offices of corruption).

To kill and divide means to have and share the spoils of office, to make money or get something 
somehow, usually illegally or questionably, and then share.

Jack

Informal ENE for to read or reading: "Students are jacking seriously for their exams."

Light

It is additionally used to mean electric power/energy for different uses. "There is no light in the Department."

Madam (95\% entrenched in informal English).

In addition to its SBE senses, madam is further used as a word of respect for all categories of women generally in ENE, particularly when they are educated and fashionable. It is equally used as a respectable address for one's wife: Speaker A: "How is your madam?" Speaker B: "My madam is fine at home." Madam here is a respectable reference to speaker B's wife. You here such phrases as Oga madam, our madam, Madam Rachel, Madam Rose, etc.

\section{Mess/to mess}

In addition to its SBE and dictionary sense, mess is often used in informal ENE for SBE fart or to fart: "Who messed this smelly mess?"

Mobile

It is used for a vehicle or car in ENE: "Are you mobile?" meaning "Do you have a car or did you come with a car?

\section{My woman/your woman}

Informally used to mean 'my wife' or 'my girlfriend' or my mistress; 'your wife,' 'your girl.' Also 'my man,' 'your man': "My woman is waiting for me outside."

Pepper (88\% entrenched).

Pepper, a hot green or red fruit, used as condiment, has added metaphoric extension in ENE. It is additionally used to denote punishment, a bad experience, suffering, inconvenience, trouble, a trying situation, etc. "I saw pepper on that day. The man showed me pepper."

Pretty (90\% entrenched)

In SBE, pretty for beauty means attractive, good-looking but not very beautiful. In ENE, it means very beautiful and attractive: "His wife is a pretty woman." SBE sense of pretty as an adverb means very, highly; for example: "I know the man pretty well." This adverbial sense of the word as very then intraferes with the adjectival sense of pretty in ENE.

\section{Purge/to purge}

The sense of SBE purgative is extended to purge in ENE where to purge means to have or feel a runny stomach or to take purgative so that one can disembowel easily. I am purging (myself) either means that I am taking laxative or purgative to disembowel easily or I have runny stomach.

Rewind

In SBE, it means to play a tape backwards. This has been extended to mean repeat what you said, recapitulate, say it again in ENE: "Please rewind sir. I didn't hear you." Come again is also popularly used in the sense of SBE Pardon? Excuse me? etc.

Runs (95\% entrenched)

Some kind of fast activities done urgently to achieve a result, e.g., school runs: going to school to drop and pick up children. It also denotes shady deals, sexual meetings, etc done quickly and secretly. One often hears of runs girl or runs guy, which means a girl into sex for quick money or a guy into some sharp business.

See

It could denote to give bribe or something else, to recognize, to acknowledge, to consult, to settle, etc: "You have to see me. If you don't see me, I won't vote for you in this election."(A statement from a voter to a politician campaigning to be elected to an office in 2007).

Several (95\% entrenched in both informal and formal ENE). 
Several usually denotes more than two or up to three, some but not many in SBE. In ENE, several has been strengthened to include many or very many: "Several of Major Al Mustapha's friends and relative were in the court... for several hours" (Oboh, 2012).

In this report, the court was besieged with many of Mustapha's relations and friends during his judgment which took many hours.

\section{Spill over}

Students spending extra years in higher institutions after the regular four or five years for a degree programme; a course being retaken at this time: "The spillover sheet is not ready yet."

\section{To take light/cease light}

Often used in ENE for SBE to cut or interrupt electric power. "They have taken light." "NEPA has ceased light."

\section{Uncle/aunty}

In addition to its SBE sense, uncle/aunty in ENE is a term of respect that pupils and students use to address their teachers; for example, our Maths Uncle, Physics Uncle. Children and adults also use it for a male senior or elder to show respect; often attached to the person's name like a title, e.g., Uncle Rufus, Uncle Segun, Aunty Rose, etc even when the person is not truly an uncle/aunty by family connections.

Although the process of English meaning extension has been used to add extra meaning to this word, for an equivalent lexical word for uncle does not exist in most Nigerian languages, this meaning extension is reinforced by sociolinguistic and cultural factors: In most Nigerian languages and cultures, particular in Yoruba, younger ones do not just mention the names of their elders and seniors when addressing them. So, one hears Brother Steve, Sister Veronica, Uncle Victor, Aunty Agnes, etc.

\section{Vacate}

In addition to its regular SBE/dictionary meaning, it is used in ENE to mean 'go on holiday or have a break from school, an extension of the meaning of its noun derivative: vacation.

\section{Village/villa}

It is used to denote a rural area and one's native home or place of birth even though the place may not be a village in its dictionary or SBE meaning: "We are going to the village for Christmas."

Well done/welldone ( $100 \%$ entrenched).

In SBE, you say well done when you are pleased with a completed piece of action or work. It is also used to describe well-cooked foods. However, in ENE, well done/welldone is additionally used pragmatically to appreciate, greet or encourage those who are at work, sitting, eating, just relaxing or doing something: "Well done sir!" This means the person being greeted/addressed is working, doing something or just being appreciated.

\subsection{Lexico-Semantic Intraference by Conversion}

Block/Blocking ( $96 \%$ entrenched).

Block is a noun also used as a verb by conversion in SBE. In Nigeria, the verb form of block has assumed a different meaning: Block/blocking now denotes a notorious and morally condemnable practice of bribing lecturers and members of staff in an institution and other places with money, gifts and sex to get pass marks, influence examination result or achieve a purpose. "Last September, I spent more than fifty thousand naira to block my lecturers." It is also called "sort/sorting."

\section{Finger/Fingering}

Although finger, a noun, is also used as a verb in SBE, it is further used in a sexual sense in ENE. It denotes men's habit of inserting (a) finger(s) into a woman's genitals to tickle or arouse her. "He only fingered the girl," in native English, would mean He only identified or pointed her out, but in ENE, it means that he only inserted his finger into the girl's privates without having real sex with her.

Flit

Generally used for all brands of insecticide in all varieties of NE, including informal ENE. Also used in the sense of to fumigate in SBE: "Please, buy me flit to flit all these mosquitoes?" 


\section{Gallop}

Through conversion, gallop is used as a noun meaning potholes: "There are too many gallops on the Benin-Lagos road."

\section{Host/hosting}

In ENE, this means to receive, accommodate, entertain a guest, friend, club members, a meeting of a grop to which one belongs "I am hosting my club on Sunday." in SBE, play host is the more regular variant.

Romance ( $85 \%$ widespread).

In ENE, romance (v) has extra layers of meaning different from the SBE sense. Educated Nigerians use it to denote the following: (i) cuddle, caress, neck, smooch or have foreplay before sex or without sex, (ii) to have a sort of questionable sexual or social relationship with someone or a group; for example, 'Darling, if you don't romance me, I will romance you' (Under Fire, a Nigerian film / 'Home Video'). "Romancing Nollywood at the expense of other art forms..." (Ajeluorou, 2013, p. 27).

\section{Zone/zoning}

In SBE, zone is an area of land or farm and to zone is to share an area of land or mark it out clearly. But in ENE, it is extended to mean to rotate power, particularly political power, office and leadership, to a specific village, ward, tribe, or geo-political zone. Zoning is the lexicalization of this political policy "In conformity with power sharing and zoning principle, the President and Vice-presidential candidates have to be alternately picked from either north or south... the Zoning Principle of equity in representation and power sharing is now invariably adopted..."(Igbafe, 2006, p. 8).

\subsection{Cases of Semantic Weakening}

\section{Bastard}

Bastard primarily denotes a child born out of wedlock in SBE, but this has become old-fashioned or weakened. It is now mainly used to insult, express sympathy and show understanding, e.g., Oh, poor bastard that you are! But in ENE, bastard is not used to express sympathy or to describe a child born out of wedlock so long as the child's father is known. So, this sense of the word is weakened in ENE. Conversely, it has been strengthened as a tag for a child who does not know his/her father or who has been given to the wrong father or whose paternity is in dispute. It is also regularly used as an insulting word.

Impeach/ment ( $98 \%$ entrenched).

"I saw hell after my impeachment" (Obi, p. 12).

Shoemaker $(100 \%$ entrenched)

In NE, a shoemaker is not a maker of shoes, as the word suggests, but one who repairs and polishes shoes. Those who make or build new shoes are often called shoe-designers in ENE.

\section{Vendor(s)}

It is restrictively used for (a) newspaper seller(s) in ENE.

\subsection{Semantic Reversal}

\section{Bad}

In informal ENE, bad is sometimes used to humour, flatter, praise or commend: "My God! JJ Okocha is a bad dribbler! See the way he dribbled three defenders at once!" "Men! Shake my hands! I like the way you handled her. You are a bad guy!" Bad is often used in this sense when what is done may be considered bad to the victim, but somehow necessary, appropriate and expected of the doer.

\section{Dowry (95\% entrenched)}

In section 2 of the Customary Marriage Law 1956 (now Chapter 38 of the Revised Laws of Anambra State, 1991), dowry is defined as follows: 'Any gift or payment in money, natural produce, brass rods, cowries or any kind of property whatsoever, to parent or guardian of a female person on account of a marriage of that person which is intended or has taken place. (Okafor, 2005, p. 10).

This legal definition, which is SBE bride price, is true of the meaning and usage of dowry all over Nigeria. Interestingly, this usage and definition is now in the entry of the word dowry in the New Advanced Learner's 


\section{Dictionary.}

\section{Trouble-shooter}

Going with its computer sense of problem solver or killer, 'trouble-shooter' has in informal ENE the converse meaning of a trouble-maker or trouble-giver, one who disturbs or shoots (out) trouble to inconvenience others.

Table 2. Summary table for the lexico-semantic cases examined

\begin{tabular}{lllll}
\hline Entrenched & Widespread & Common & Emerging & Total \\
\hline Fifty-four (54): 75\% & Eighteen (19): 25\% & Nil: 0\% & Nil: 0\% & Seventy-two (73): 100\% \\
\hline
\end{tabular}

\section{Conclusion}

As shown in this paper, lexico-semantic intraference is a productive process that educated Nigerians (re)deploy to invest extant English words with new or additional meanings or coin words with new meanings which may not be in SBE. This is unlike lexico-semantic interference in which nonnative users of ESL transfer the semantic features of their native and/or first languages to English or their second language. In lexico-semantic intraference, meanings and lexico-semantic processes are redeployed from one section of the language where they are established to another section where they used not to operate. In doing this, nonnative speakers in an ESL situation produce words and meanings that distinguish their variety. Educated Nigerians, under such psycho-sociolinguistic constraints as the pressure of communication, the need for brevity, the creative urge, awareness of usage and ignorance, the dynamics of the language and ESL settings, etc redeploy lexico-semantic rules to fabricate words and meanings that may not be found in SBE or whose meanings are already well expressed in some other established SBE words. This entrenched habit among educated Nigerians produce lexical items that then distinguish ENE lexico-semantics from SBE and other international English lexico-semantics.

\section{References}

Adegbija, O. (1989). Aspects of lexico-semantic variation in Nigeria English. World Englishes, 8(2), 165-177. http://dx.doi.org/10.1111/j.1467-971X.1989.tb00652.x

Aitchison, J. (2001). Introduction. Words pour into English. In Longman Dictionary. London: Longman.

Ajeluorou, A. (2013, May 10). Jonathan's romance with Nollywood. The Guardian, 25.

Akmajian, A., Dermer, R., Farmer, A., \& Harnish, R. (2006). Linguistics: An introduction to language and communication (4th ed.). New Delhi: Prentice Hall.

Bayley, R., \& Lucas, C. (Eds.). (2007). Sociolinguistic variation: Theories, methods, and applications. Cambridge: Cambridge University Press. http://dx.doi.org/10.1017/CBO9780511619496

Bamiro, E. (1994). Lexico-semantic variation in Nigerian English. World Englishes, 13(1), 42-61. http://dx.doi.org/10.1111/j.1467-971X.1994.tb00282.x

Banjo, A. (1996). Making a virtue of necessity: An overview of the English language in Nigeria. Ibadan: Ibadan University Press.

Chomsky, N. (1965). Aspects of the theory of syntax. Cambridge: MIT Press.

Crystal, D. (2009). A dictionary of linguistics and phonetics (6th ed.). Oxford: Blackwell Publishers.

Effiong, C. O. (2011). Semantic contrasts in Educated Nigerian English. In I. Udofot, \& J. Udoudom (Eds.), English usage in Nigeria since 1842 patterns and changes (pp. 286-296). Ikot Ekpene: Devconsort Publishers.

Ekundayo, O. B. S. (2006). The concept of 'inraference' in English as a second language: Examples from Nigerian English (Master's thesis). University of Benin, Benin, Nigeria.

Ekundayo, O. B. S. (2012). 'Intraference' in Educated Nigerian English. A Ph.D. research design and proposal. University of Benin, Benin, Nigeria.

Funks, \& Wagnalls. (1975). Standard desk dictionary. Vol. I. (A-M). New York: Funks \& Wagnalls.

Igbafe, P. (2006). Before the axe falls: History and the humanities in our national life. Benin: University of 
Benin Press.

Jowitt, D. (1991). Nigeria English usage: An introduction. Lagos: Longman.

Jowitt, D. (2008). Varieties of English in Nigeria. Inaugural Address. University of Jos, Jos, Nigeria.

Labov, W. (1963). The Social motivation of sound Change. Word, 1, 273-309.

Labov, W. (1972). Language in the Inner City: Studies in the Black English Vernacular. Philadelphia: University of Pennsylvania Press.

Labov, W. (1994). Principle of linguistic change: Vol. I. Internal factors. Oxford: Blackwell.

Labov, W. (1994). Principle of linguistic change: Vol. II. External factors. Oxford: Blackwell.

Labov, W. (2010). Principle of linguistic change: Vol. II. cultural factors. Oxford: Blackwell. http://dx.doi.org/10.1002/9781444327496

Maduagbunam, A. (2011, April 23). NTA News at 9.p.m. Lagos.

Milroy, L. (2008). Sociolinguistics: Models and Methods. Retrieved July 20, 2012, from http://www.onlinelibrary.wiley.com/doi 10.1002197804758359

Omorogiuwa, O. K. (2006). Research and applied statistics for the behavioural sciences. Benin: Mindex Publishers.

Obi, P. (2008, August 31). I saw hell after my impeachment. Sunday Sun, 12.

Oboh, S. (2012, January 30). STV News. Silver Bird Television, Lagos.

Odumuh, A. O. (1980). The syntax and semantics of Nigerian English (Doctoral dissertation). University of Zaria.

Okafor, A. (2005). Awka system of marriage: The best in the world. Awka: Mercury Bright Press.

Osakwe, M. (2011). Tending, bending breaking vagabond English for global use and needs. 24th inaugural lecture of Delta State University, Abraka: Delta State University Press.

Richards, J. C. (Ed.). (1984). Perspective on second language acquisition. London: Longman.

Teilanyo, D. I. (2008). Neologisms in Nigerian English. Uyo Journal of Humanities, 13, 28-51.

Selinker, L. (1971). The psychologically relevant data of second-language learning. In P. Pimsleur, \& T. Quinn (Eds.), Psychology of second language LEARNING (pp. 35-43). London: Cambridge University Press.

Selinker, L. (1984). Interlanguage. In J. C. Richards (Ed.), University Examination Script. ENL 214 (pp. 1-54). ART 0900332, 2011: 3.

University Examination Script. ENL 114. First Semester. Art 0900355, 2011: 2.

University Examination Script. ENL 114. First Semester. Art 0900255, 2011: 2.

University Examination Script. ENL 414. First Semester. Art 0800255, 2012: 2.

Yule, G. (2003). The study of language. Cambridge: Cambridge University Press.

\section{Appendices}

\section{Appendix A}

\section{QUESTIONNAIRE ON LEXICO-SEMANTIC VARIATIONS IN ENE}

The questions below are designed to generate data for a research work on Educated Nigerian English (ENE). Kindly shade, ring or tick any of the sets of expressions (A or $\mathbf{B}$ mainly, and sometimes $\mathbf{C}$ and $\mathbf{D}$ ) that you use regularly when you speak or write, with particular reference to the italicized items. Be fair and truthful with your answers. The issue is NOT whether the option you regularly use is right or wrong, but whether you use it regularly. Where you use the two, tick or ring the two, but tick or ring twice the one you use more often/regularly.

Sex-----Age----Qualification/rank---------------School/Place of work -Department-

Native language-Date-

1. To impeach a government official means---- (A) to indict, accuse him/her. (B) to remove him/her from office by parliamentary votes. 
2. When you use the word diabolic to describe someone (for example, He is a diabolic man), you mean (A) someone who is wicked. (B) A witch/wizard or someone who,

3. Some Labour Party members have---to PDP. (A) defected. (B) decamped.

4. Which of this do you say when are want a driver to stop and drop you? (A) Driver, I want to step down. (B) Driver, I want to come down

5. To take in is (A) to deceive or trick. (B) to be or get pregnant.

6. When you use the word celebrant, you mean (A) one who is celebrating a birthday, appointment, house inauguration, promotion, success, etc (B) a priest conducting Mass or religious rituals

7. A flirt is (A) someone who keeps several opposite sex friends but does not necessarily have sex with them (B) someone who keeps several opposite sex friends and has sex with them.

8. What do you call the money Christian normally give during church service? (A) offertory (B) offering.

9. To toast a lady means (A) to cook her like bread (B) to talk sweetly to her to win her love

10. A dash means (A) a quick action (B) something given free, a gift.

\section{Appendix B}

\section{ADDENDUM TO QUESTIONNAIRE ON LEXICO-SEMANTIC VARIATIONS IN ENE (ADMINISTERED IN THE UNIVERSITY OF BENIN)}

The questions below are designed to generate data for a research work on Educated Nigerian English (ENE). Kindly shade, ring or tick any of the sets of expressions (A or $\mathbf{B}$ mainly, and sometimes $\mathbf{C}$ and $\mathbf{D}$ ) that you use regularly when you speak or write, with particular reference to the italicized items. Be fair and truthful with your answers. The issue is NOT whether the option you regularly use is right or wrong, but whether you use it regularly. Where you use the two, tick or ring the two, but tick or ring twice the one you use more often/regularly.

Sex----Age-----Qualification/rank---------------School/Place of work----------------------Department-----------------

Native language-------------------Date-

1. The girl is forming means (A) making/forming something. (B) pretending.

2. Vincent left me just now to go home and crash a little. (A) fall or collapse (B) sleep.

3. A woman wrapper is (A) a wrapper/cloth for women. (B) a womanizer or man who does anything to please his wife, girlfriend or mistress.

4. When you use the word several, you mean (A) up to two but not more than three, or few. (B) more than three or many.

5. Do you use the word madam for someone's wife, as in how is madam? (A) No (B) Yes.

6. Dr Ogha is chasing that girl means (A) running after her physically. (B) wooing, asking her for sexual love.

7. You are speaking/blowing grammar to us. (A) You are speaking good grammar/English. (B) You are speaking what we do not understand.

8. The word runs as you use it is (A) some running (B) deals and socio-economic activities, good or bad, that one does to make money.

9. I saw pepper that very day means (A) I saw hot pepper as soup ingredient. (B) I suffered.

10. Do you often greet someone who is working or doing something welldone? (A) No (B) Yes.

11. (A) To block or blocking someone means----(A) to stop or prevent someone (B) to bribe someone, particularly a lecturer, to pass an exam or get higher grades.

12. (A) We caught them----each other each other. (A) cuddling/fondling (B) romancing.

(A) A shoemaker is one who (A) makes shoes (B) repairs and polishes shoes.

13. What do normally say to a driver when you want him to drop you at a place or bus stop? Stop! I want to alight or step down (B) Stop! I want to come down or go down.

14. When you use the word pretty to describe a girl, you mean that----(A) she is not so beautiful but just averagely okay or beautiful. (B) You mean she is very beautiful or attractive. 


\section{Copyrights}

Copyright for this article is retained by the author(s), with first publication rights granted to the journal.

This is an open-access article distributed under the terms and conditions of the Creative Commons Attribution license (http://creativecommons.org/licenses/by/3.0/). 